\title{
Measurement of Economic Development and Interdependence of Countries
}

\author{
Larisa Korganashvili
}

Doctor of Economic Sciences, Professor, Ivane Javakhishvili Tbilisi State University, Tbilisi, Georgia

\begin{abstract}
At the present time to assess countries economic development, mostly used indicators are per capita GDP and GDP. However, these indicators do not sufficiently reflect the level of economic development of countries. In this regard, for clarification of GDP a correction factor and to determine the interdependence of countries - the interdependence factors are proposed.
\end{abstract}

Keywords: Economic development, GDP, interdependence of countries, indicators.

\section{Introduction}

Economic development of a country is a multifaceted process, which is evaluated by the whole system of indicators. World Bank measures economic development on a national and global scale with more than 2000 indicators. Among them, in practice, the most used are GDP and GDP per capita. However, these indicators do not sufficiently reflect the level of economic development. In its turn the interdependence of countries has become an axiom of the modern world, so it is advisable to determine the level of dependence of one country on another, or on the global economy as a whole.

Purpose of this study is to propose new indicators for further economic development of the national and global economy and determine the interdependence of countries.

\section{Methodology and results.}

1.For the economic development of the national and global economy it is offered to use the correction coefficient $\mathrm{C}_{\mathrm{cor}}$ and use it to correct the GDP of the country or the world. In this case

$\mathrm{GDP}_{\text {cor }}=\mathrm{GDP} \cdot \mathrm{C}_{\text {cor }}(1)$

where $\mathrm{GDP}_{\text {cor }}$ is corrected volume of GDP, $\mathrm{C}_{\text {cor }}$ - correction coefficient, representing an average of 5 indicators. In turn $\mathrm{C}_{\text {cor }}$ calculated as follows:

$\mathrm{C}_{\text {cor }}=\frac{\frac{\text { GDP }}{\text { population }}: \frac{\text { GDP }}{\text { labor force }}+\frac{\text { GDP }}{\text { total area }}: \frac{\text { GDP }}{\text { economic efficiency area }}+\frac{\text { export }}{\text { import }}+\frac{\text { domestic investment }}{\text { direct foreign investment }}+\frac{\text { domestic debt }}{\text { external debt }}}{5}$

(2)

After the conversion formula (2) takes the form:

$\mathrm{C}_{\text {cor }}=\frac{\frac{\text { labor force }}{\text { population }}+\frac{\text { economic efficiency area }}{\text { total area }}+\frac{\text { export }}{\text { import }}+\frac{\text { domestic investment }}{\text { foreign direct investment }}+\frac{\text { domestic debt }}{\text { external debt }}}{5}$

For example, for Georgia labor force $=1,991.1$ thousand people, population $=4,490.5$ thousand people, economic efficiency area $=52.3$ thousand sq. $\mathrm{km}$. , total area $=69.7$ thousand sq. $\mathrm{km}$., $\quad$ export $=2,860,671$ thousand USD, import= 8,593,325 thousand USD, domestic investment $=4,050.9 \mathrm{mln}$ USD, 
foreign direct investment $=1,758.4 \mathrm{mln}$ USD, domestic debt $=1,008,381$ thousand USD, external debt $=$ $4,199,798$ USD

With the formula (3) $\mathrm{C}_{\mathrm{cor}}=\frac{\frac{1991.1}{4,490.5}+\frac{52.3}{69.7}+\frac{2,860,671}{8,593,325}+\frac{4,050.9}{1,758.4}+\frac{1,008,381}{4,199,798}}{5}=\frac{0.44+0,75+0.33+2.30+0.24}{5}=0,812$

Respectively based on the formula (1)

$\mathrm{GDP}_{\text {cor }}=16507.8 \mathrm{mln} . \mathrm{USD} \cdot 0,812=13404.3 \mathrm{mln} . \mathrm{USD}$

2. The interdependence of countries can be characterized by coefficient of interdependence, which is calculated by the formula:

$\mathrm{C}_{\mathrm{in}}=$

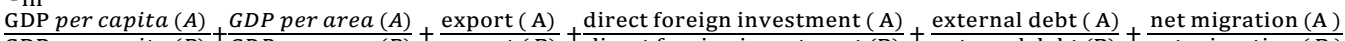
$\frac{\text { GDP per capita }(B)}{\text { GDP per area }(B)}+\frac{\text { export (B) }}{\text { direct foreign investment (B) }}+\frac{\text { external debt (B) }}{\text { exet migration (B) }}$

(4)

Where $C_{\text {in }}$ is coefficient of interdependence, representing an average of 6 indicators, GDP per capita (A) - GDP per capita of the country A, GDP per capita (B) - GDP per capita of the country B, GDP per area (A) - GDP per area of the country A, GDP per area (B) - GDP per area of the country $B$, export (A) - export of country $A$ to country $B$, export (B) - export of country $B$ to country $A$, direct foreign investment $(A)$ - direct foreign investment of the country $A$ to country $B$, direct foreign investment $(B)$ - direct foreign investment of the country $B$ to country $A$, external debt $(A)$ - external debt of the country $A$ to country $B$, external debt $(B)$ - external debt of the country $B$ to country $A$, net migration $(A)$ - net migration of the country $A$ to country $B$, net migration $(B)$ - net migration of the country $B$ to country $A$.

Table 1. Data for calculating the coefficient of the interdependence of Georgia and Azerbaijan

\begin{tabular}{|l|l|l|}
\hline & Azerbaijan & Georgia \\
\hline GDP, billion USD & 53.05 & 13.97 \\
\hline GDP per capita, USD & $5,496.3$ & $3,796.0$ \\
\hline GDP per area, USD & 612,587 & 205,743 \\
\hline Export, mIn. USD & 539.0 & 241.0 \\
\hline Foreign direct investment, mIn. USD & 550 & $\mathrm{~N} / \mathrm{A}$ \\
\hline External debt, & $\mathrm{N} / \mathrm{A}$ & 11,512 \\
\hline Net migration & 1,574 & 2,839 \\
\hline $\begin{array}{l}\text { Source: } \text { http://www.worldbank.org/en/country } \\
\text { http://geostat.ge/index.php?action=0\&lang=eng }\end{array}$ & \\
\hline http://www.stat.gov.az/indexen.php & \\
\hline
\end{tabular}

Substituting the values of the indicators presented in Table 1 in the formula (4) we obtain (because of missing data of foreign direct investment and External debt calculation is made on the four indicators)

$\mathrm{C}_{\mathrm{in}}=\frac{\frac{3,796.0}{5,496.3}+\frac{205,743}{612,587}+\frac{241.0}{539.0}+\frac{2,839}{1,574}}{4}=0,82$

Note that if $\mathrm{Kv}=1$, in this case partners have roughly equal parameters and they are in an equilibrium position. If $\mathrm{Kv}<1$, the country A depends on the country B (calculations showed that Georgia is to a certain extent depends on Azerbaijan), and if $\mathrm{Kv}>1$, on the contrary: the country B depends on the country A. The higher Kv, the lower the country's dependence A from country $B$. 


\section{Conclusion}

GDP correction factor which is proposed in the study, allows for a fresh look at the essence of the economic development of the countries and on the basis of the coefficient of interdependence among countries to determine their degree of interdependence.

\section{Reference}

[1] http://geostat.ge/index.php?action=wnews archive1\&qy=1\&qy1=16\&lang=eng, http://www.mof.ge/en/4435

[2] http://geostat.ge/index.php?action=wnews_archive1\&qy=1\&qy1=16\&lang=eng, http://www.mof.ge/en/4435 